\title{
THE IMPACT OF GREEN ROOFS ON THE QUALITY OF RAINWATER AND OPERATIONAL PROBLEMS - CASE STUDY
}

\author{
Agnieszka Boas Berg ${ }^{1}$, Dana Adamcová2, Petra Martínez Barroso², \\ Markéta Šourková2, Magdalena Daria Vaverková2 ${ }^{凶}$ \\ ${ }^{1}$ Shada BV, the Netherlands \\ ${ }^{2}$ Faculty of AgriSciences, Mendel University in Brno
}

\begin{abstract}
Shopping centres usually occupy large areas of land development. However, their roofs are rarely used for purposes related to rainwater management and introduction of active biological surfaces. In Bielsko-Biała, thanks to the initiative of the originator and architect, an intense green roof was created on the rooftop of a shopping centre. In addition to the primary role of the roof as a garden that makes the housing estate more attractive, it also collects some of the rainwater and delays its outflow to the sewage system. Plants, shrubs and trees planted on the roof are watered almost exclusively with water collected in a tank located under the building, intended for retaining rainwater. These waters are pretreated before they reach the tank, i.e. they filter through the root layer of plants growing on the roof, and through the biologically active layer (substrate). This paper highlights some of the operating problems of the selected green roof. The authors focused on assessing the toxicity of rainwater flowing down from hardened surfaces on the roof of the shopping centre and the area occupied by the green roof. Relevant toxicity studies on these waters have been carried out in this regard. The research hypothesis that rainwater percolating through the selected soil material is not toxic and stimulates test plant growth was put forward. Tests of semichronic toxicity with the seeds of white mustard (Sinapis alba L.) prove that all the rainwater samples showed a stimulating effect on the test plant. The average root growth stimulation value during the period considered was $-125 \%$. It was confirmed that rainwater did not show toxic properties for white mustard seeds (Sinapis alba L.) and can be used for watering the garden constituting the green roof of a selected research facility. In the case of rainwater $\mathrm{pH}$, it was found that the $\mathrm{pH}$ is adequate and has no toxic effect on the selected white mustard test plant (Sinapis alba L.). It confirms that the rainwater retained in this way can be used to water the green roof. The selected research facility meets the requirements set for green roofs.
\end{abstract}

Key words: environment, green roof, rainwater, phytotoxicity test, Sinapis alba L.

\section{INTRODUCTION}

In recent years, urbanization is a strong trend around the world. Constant urbanization does not only lead to economic development but also puts great pressure on existing infrastructure in cities (Lin \& Zhu, 2018). Excessive rainwater runoff from urbanized areas (large paved areas in cities) causes rapid floods and problems related to the deterioration of the quality of groundwa- ter and rivers (Shafique \& Kim, 2017; Shafique, Azam, Rafiq, Ateeq \& Luo, 2020). Under these circumstances, there is a great need for a green and sustainable practice that would help restore balance by allowing green spaces such as green roofs or periodically flooded surfaces (wadi) to make evapotranspiration or delayed water infiltration into the ground possible (Shafique et al., 2020). In urban areas, the roof area accounts for about 
Boas Berg, A., Adamcová, D., Martínez Barroso, P., Šourková, M., Vaverková, M. D. (2020). The impact of green roofs on the quality of rainwater and operational problems - case study. Acta Sci. Pol. Architectura, 19 (1), 31-41. doi: 10.22630/ASPA.2020.19.1.4

$40-50 \%$ of the total impervious urban area (Stovin, 2010). These areas offer great opportunities to use green roofs to promote sustainable development and a cleaner environment in urban areas (Berardi, GhaffarianHoseini \& GhaffarianHoseini, 2014; Teotónio, Silva \& Cruz, 2018; Shafique et al., 2020). Therefore, green roofs are currently widely used in urban buildings, mainly new ones. They contribute to the re-naturalization (revitalization) of cities (Versini, Gires, Tchiguirinskaia \& Schertzer, 2020). Green roof are recognised as multi-functional tools that can perform many functions in the ecosystem (Francis \& Jensen, 2017; Baryła, Gnatowski, Karczmarczyk \& Szatyłowicz, 2019), namely counteracting climate change or unsustainable urbanisation. Green roofs are particularly important in thermal regulation (Ouldboukhitine, Belarbi \& Sailor, 2014; Suter, Maksimović \& van Reeuwijk, 2017). They can mitigate the effect of so-called urban heat island (Bowler et al., 2010), are important for urban biodiversity (Madre, Vergnes, Machon \& Clergeau, 2014; Versini et al., 2020), have a positive impact on urban air quality (Speak, Rothwell, Lindley \& Smith, 2012), but above all have a significant impact on urban water management (Versini, Gires, Tchinguirinskaia \& Schertzer, 2016; Baryła, Karczmarczyk \& Brandyk, 2018; Baryła, Karczmarczyk \& Bus, 2018; Versini et al., 2020). Green roof significantly reduce stormwater runoff, easing the peak and runoff volume (Speak et al., 2012; Zhan et al., 2015; Palermo, Turco, Principato \& Piro, 2019). In addition, they can also affect the aesthetic and social aspects of the city (Jungels, Rakow, Allred \& Skelly, 2013). Furthermore, extensive implementations of green roof (including mining, production and transport of raw materials, construction, operation, maintenance and recycling of materials) can cause several environmental and economic burdens (Law, Diemont \& Toland, 2017), especially on existing facilities that are not always structurally adapted for such development.

The paper highlights some of the operating problems of the selected green roof. The authors focus on the assessment of rainwater toxicity from hardened surfaces on the standard roof and green roof of the shopping centre. The research hypothesis that rainwater percolating through the selected object is not toxic and stimulates test plant growth has been formulated.

\section{MATERIAL AND METHODS}

\section{Site location}

The research subject was an intensive green roof located at shopping centre "Sfera II" in Bielsko-Biała. The city is located in the southern part of the Ślaskie Voivodeship $\left(49^{\circ} 49^{\prime} 21^{\prime \prime} \mathrm{N}, 19^{\circ} 02^{\prime} 40^{\prime \prime} \mathrm{E}\right)$. The greater part of the city of Bielsko-Biała lies in the Silesian Foothills, which is part of the macro-region of the Western Beskids Foothills (Fig. 1).

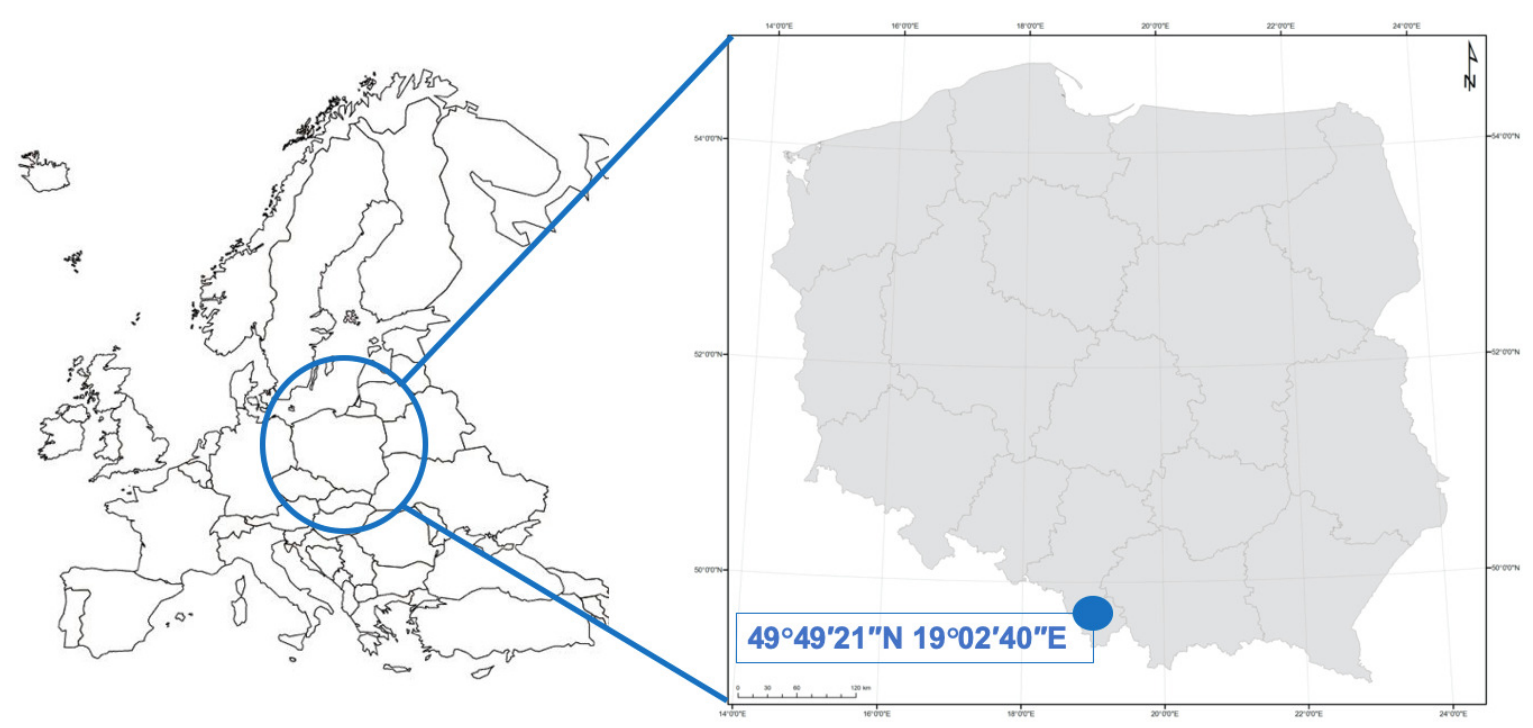

Fig. 1. Study site location 
Boas Berg, A., Adamcová, D., Martínez Barroso, P., Šourková, M., Vaverková, M. D. (2020). The impact of green roofs on the quality of rainwater and operational problems - case study. Acta Sci. Pol. Architectura, 19 (1), 31-41. doi: 10.22630/ASPA.2020.19.1.4

The area of the city of Bielsko-Biała is about $124.51 \mathrm{~km}_{\iota}$, including residential areas: $16.4 \%$, service areas: $2.6 \%$, industrial and storage areas: $3.6 \%$, communication areas: $11 \%$, agricultural areas: $14.6 \%$, forest areas: $24.2 \%$, urban greenery: $2.2 \%$, and other areas: $25.4 \%$. The city is a tourist attraction of the region. It lies along the route leading to the border crossings in Cieszyn and Zwardoń, as well as to sports and tourist centres in Szczyrk, Ustron or Wisła. In the Bielsko road node, several roads of national importance converge, i.e.: 1 (S1), 52, (S52), 940, 942 and 944.

The city's area is located within two climatic districts: Podkarpackie Foothills and Carpathians, which causes irregular weather conditions, including hightemperature fluctuations and variable distribution of precipitation in the annual cycle. Western and southwestern winds prevail during the year. In winter, southwestern and southern winds (including halny - strong mountain wind) are more frequent; while in the summer, western and north-western winds prevail. The highest cloudiness occurs from November to January, and the highest number of sunny days occurs between the end of summer and the beginning of autumn.

\section{Description of the research facility}

In Bielsko-Biała, thanks to the initiative of the originator and architect, an intense green roof was created on the shopping centre. This roof serves primarily as a garden that makes the housing estate in the city centre more attractive. Plants, shrubs and trees planted on the roof are watered almost exclusively with water collected in the retention tank intended for rainwater. These waters are pretreated before they reach the tank, i.e. they filter through the root layer of plants growing on the roof, and through the biologically active layer (substrate).

A housing estate has been designed and built on the shopping centre's roof. The creator of this concept is the architect Ireneusz Hendel (Project Galeria Sfera expansion..., 2007-2010). The inner courtyard of the estate houses a garden with an area of approx. $2,300 \mathrm{~m}^{2}$. It is an intense garden, with a larger ground cover containing tall plants and trees such as birches, hornbeams and maples. It also comprises smaller plants such as rose shrubs, wild vines and lavender. The surface of the garden is covered with various grass species. The roof is biologically diverse. During the flowering season, it is home to honey bees and scythes that build their nests in the stands. A special irrigation system was devised to save water and consequently costs for the estate's residents - rainwater flows into tanks located below the shopping centre (the system for rainwater drainage is not connected to the municipal sewage drainage system). Rainwater from the shopping centre's roof is retained and is used to irrigate plants in the roof garden (Boas Berg, Jeznach, Radziemska, Adamcová \& Brtnický, 2018).

\section{The design and elements of the green roof used}

The structure of the layers on the examined green roof is characteristic for an intense roof. The roof surface (in the communication area, pavement paths) allows pedestrian traffic thanks to the use of concrete paving stones. The surface is adapted to pedestrian and light traffic. The concrete cube is $0.06 \mathrm{~m}$ thick and is laid on stoneware ballast ( $6 \mathrm{~mm}$ fraction) and $0.03 \mathrm{~m}$ thick sand. Gravel aggregate $(0-16 \mathrm{~mm}$ fraction) with thickness of $0.25 \mathrm{~m}$ was used on the roof in the garden area. The filter layer consists of a $200 \mathrm{~g}$ filter geotextile, which is loosely laid on the drainage layer, with longitudinal and transverse overlaps of approx. $0.2 \mathrm{~m}$. The garden part of the roof is an intensive green roof, so special layers have been used, thanks to which it is possible to grow large plants, such as shrubs or small trees. The vegetation layer consists of a $0.35 \mathrm{~m}$ thick substrate. Similar to the pedestrian roof section, protective and securing layers were used in the garden section. The next filter layer is made of $200 \mathrm{~g}$ filter geotextile, loosely laid on the drainage layer, with longitudinal and transverse overlaps of about $0.2 \mathrm{~m}$. The next drainage layer consists of a DiaDrain-40 mat with a technological overlap that is laid loosely on a protective layer, and the cavities filled with a special water-absorbing material (expanded clay). The protective layer (against mechanical damage) consists of synthetic fiber $d=0.8-1.0 \mathrm{~mm}$. This layer is placed loosely on the layer protecting against plant roots, with transverse and longitudinal overlaps with a minimum thickness of $10 \mathrm{~cm}$. A further root protection layer is made of soft $\mathrm{PVC}$ with a minimum thickness of $0.8 \mathrm{~mm}$, shaped in the form of a sealed tub loosely lying on the ground, and welded joints with 
Boas Berg, A., Adamcová, D., Martínez Barroso, P., Šourková, M., Vaverková, M. D. (2020). The impact of green roofs on the quality of rainwater and operational problems - case study. Acta Sci. Pol. Architectura, 19 (1), 31-41. doi: 10.22630/ASPA.2020.19.1.4

a $0.05 \mathrm{~m}$ overlap. The roofing, as in the area intended for pedestrian traffic, is double-layered and made of bituminous roofing felt. The first layer is reinforced asphalt roofing paper, resistant to roots. The second layer is also composed of heat-welded asphalt roofing felt with additional protection against roots in the form of copper foil $d=0.1 \mathrm{~mm}$. The next structural element is the venting or distribution layer in the form of spot glueing of the first roofing layer for thermal insulation. The next, significant layer is the thermal insulation of the flat roof made of EPS 200-036 type foam boards with a thickness of $0.24 \mathrm{~m}$. The next layer is a vapour barrier made of roofing felt with aluminium foil, point-glued to the structural layer. The final backing layer is made of cold bituminous adhesive. The basis of the entire roof is a reinforced concrete ceiling with thickness of $0.35 \mathrm{~m}$ (according to the construction design -2007-2010). The vegetation layer consists of grasses, mosses, perennials, shrubs and trees. An automatic system provides irrigation for plants. Drip irrigation was used for shrubs and perennials, and sprinkler irrigation on lawns and trees. Irrigation control is automatic and depends on the measured soil moisture. The substrate layer under the trees has been increased to $0.7 \mathrm{~m}$. The estimated water absorption in the drainage and substrate layer is about $40-50 \mathrm{dm}^{3} \cdot \mathrm{m}^{-2}$. Figure 2 is a scheme showing the examined green roof of the shopping centre.

\section{Rainwater management at the shopping centre}

Rainwater from hardened surfaces on the roof building and from the roof itself, including the green roof, undergoes partial treatment by passing through the biologically active layer. A rainwater retention tank is situated under the test facility building (Fig. 2).

The retention tank with rainwater (collected from the intensive green roof) is located in the underground part of the building (level-6). The reinforced concrete tank is made of waterproof concrete walls. The tank is additionally secured on the inside with "sludge" made of "Hydrostop" type waterproofing materials. A water pump is located in the adjourning room, from which so-called grey water is pumped for watering the greenery located on the roofs and inside the shopping centre for flushing toilets. The grey water installation is independent of the water supply system from the municipal network. Rainwater consumption for sanitary purposes is computed. In accordance with the Regulation of the Minister of Infrastructure of 2002 monthly water consumption in toilets per device is $3 \mathrm{~m}^{3}$. In the sanitary installation of the shopping centre 48 cisterns are connected; hence the estimated annual water consumption in toilets is $3 \times 48 \times 12=1,728 \mathrm{~m}^{3}$, and daily water consumption for watering $2.5 \mathrm{~m}^{3} \cdot \mathrm{m}^{-2}$ (or $60 \mathrm{~m}^{3} \cdot \mathrm{m}^{-2}$ annually) equals $60 \times 2,300=13.8 \mathrm{~m}^{3}$ annually.

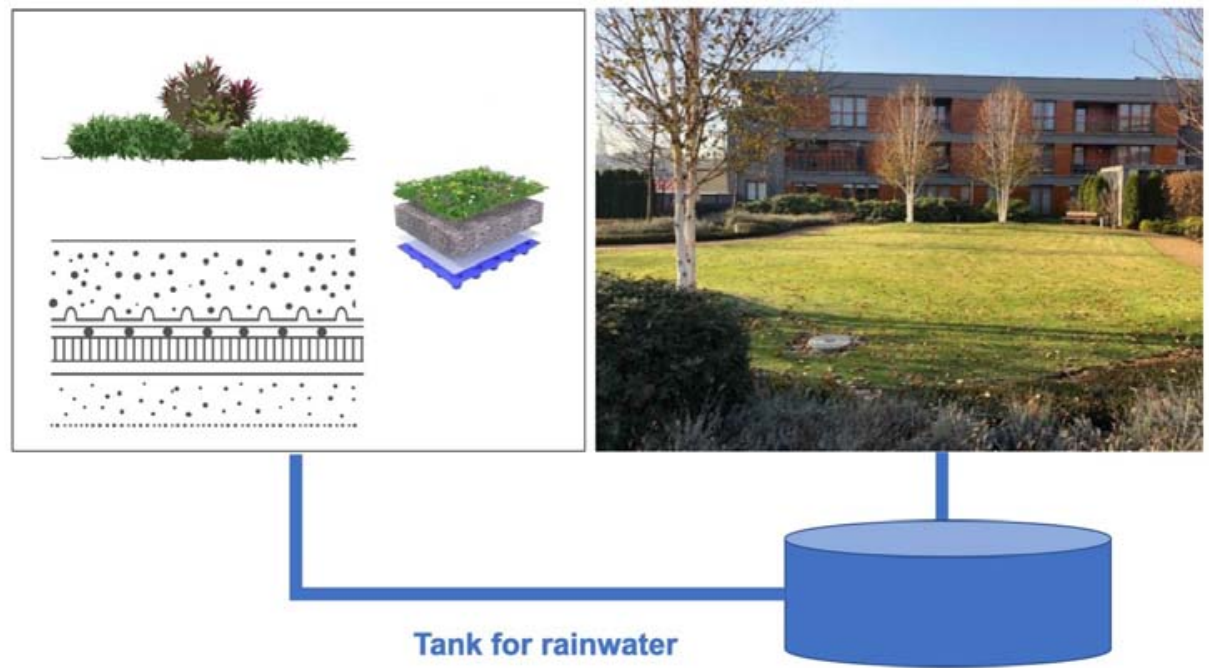

Fig. 2. Intensive green roof - shopping centre "Sfera II" (photo by A. Boas Berg, 2018) 
Boas Berg, A., Adamcová, D., Martínez Barroso, P., Šourková, M., Vaverková, M. D. (2020). The impact of green roofs on the quality of rainwater and operational problems - case study. Acta Sci. Pol. Architectura, 19 (1), 31-41. doi: 10.22630/ASPA.2020.19.1.4

\section{Test of white mustard (Sinapis alba L.) growth inhibition/stimulation on rainwater}

To determine the potential toxicity of rainwater (retained from the intensive green roof), used to irrigate plants in the garden located on the roof of the examined object, semichronic toxicity tests were conducted with the seeds of white mustard (Sinapis alba L.).

\section{Sampling of rainwater}

Rainwater was sampled in April, May, June, July, August and September 2019. Individual samples were taken from the rainwater tank and placed in sampling vessels (Fig. 3). After sampling, the vessels were properly labelled to indicate the place, and date of sampling. The samples were subsequently assessed and frozen. Semichronic toxicity tests were performed with the seeds of white mustard (Sinapis alba L.) were performed and evaluated in laboratories of the Department of Landscape and Applied Ecology at Mendel University in Brno. The samples were also analysed for $\mathrm{pH}$.

\section{Purpose and principle of the test}

Semichronic toxicity tests serve to verify potential toxicity of waters that could be used for irrigation of field plants. The aim was to determine the effect of water on the seed germination and growth of roots in white mustard (Sinapis alba L.). The principle of the test consisted in the cultivation of seeds placed on mats saturated with rainwater and their comparison with seeds growing on mats saturated with dilution water - nutrient solution (Kočí, Rakovický \& Švagr, 2001).

\section{Workflow}

Tested rainwater samples and the nutrient solution were used. Individual Petri dishes (Fig. 3) were labelled and subsequently filled with $5 \mathrm{ml}$ of nutrient solution and rainwater by pipetting. Then, filter paper was placed into each Petri dish so that it completely covered its bottom and did not form air bubbles. White mustard (Sinapis alba L.) seeds (15) places onto filter paper. The Petri dishes were then closed and placed in a thermostat at a temperature of $25^{\circ} \mathrm{C}$ for $72 \mathrm{~h}$. After $72 \mathrm{~h}$, the samples were taken out, and the root length was measured to calculate growth inhibition. Each sample was subjected to three repetitions.

\section{Test evaluation}

After 72 h, samples were taken out of the thermostat, and the root length of the plants was measured. The measured values served to calculate the arithmetic mean of root length in all repetitions. Based on these mean lengths, the root growth inhibition for the respective concentrations was calculated according to the following formula:

$$
I=\frac{D(k)-D(t)}{D(k)} 100
$$

where:

$I$ - root growth inhibition [\%],

$D(k)$ - mean root length in the control concentration [mm],

$D(t)$ - mean root length in the tested concentration [mm].
Sampling

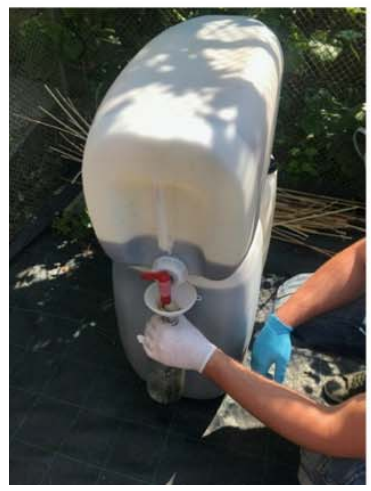

Test of white mustard (Sinapis alba L.)
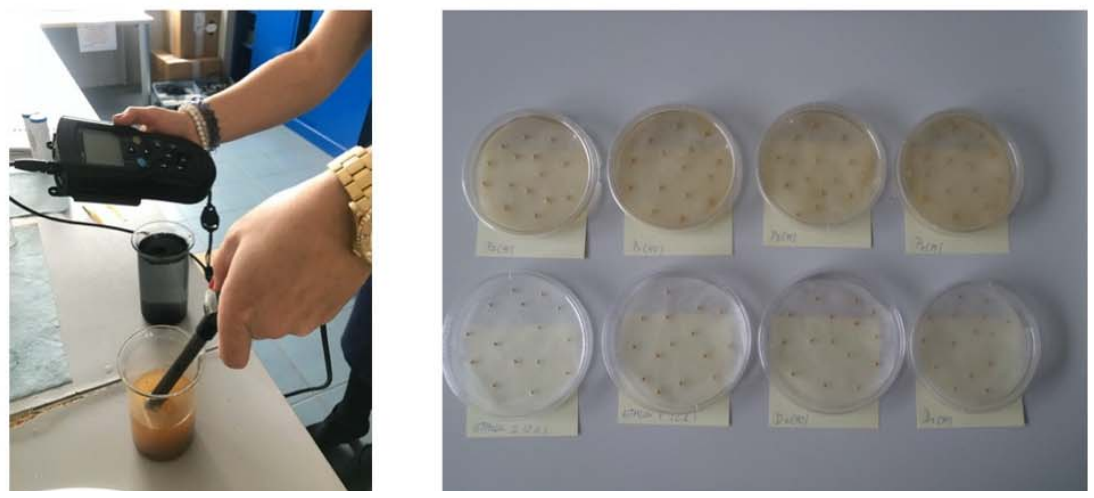

Fig. 3. Semichronic toxicity test in laboratory conditions 
Boas Berg, A., Adamcová, D., Martínez Barroso, P., Šourková, M., Vaverková, M. D. (2020). The impact of green roofs on the quality of rainwater and operational problems - case study. Acta Sci. Pol. Architectura, 19 (1), 31-41. doi: 10.22630/ASPA.2020.19.1.4

The resulting values showed growth inhibition/ /stimulation of white mustard seeds (Sinapis alba L.).

\section{RESULTS AND DISCUSSION}

\section{Water discharged from the green roof}

Great attention was paid to scientific literature in assessing the number of outflows from the green roofs, and less attention was focused in assessing the quality of water discharged (Teemusk \& Mander, 2007; Hathaway, Hunt \& Jennings, 2008; Getter \& Rowe, 2009; Van Seters, Rocha, Smith \& MacMillan, 2009; Alsup, Ebbs \& Retzlaff, 2010; Carpenter \& Kaluvakolanu 2011; Gregoire \& Clausen, 2011). Green roof can theoretically reduce rainwater pollution by absorbing and filtering pollution because they are covered with soil (soil substrate) and vegetation (Todorov, Driscoll $\&$ Todorova, 2018). Studies of nutrients in runoff from green roof have resulted in mixed findings. However, the majority of studies conclude that green roof is a source of phosphorus in runoff (Gregoire \& Clausen, 2011). It is worth emphasizing that studies carried out by Meera and Ahammed (2006) showed that conventional roof drainage exceeds the quality standards for drinking water and that pollution associated with particles in runoff from conventional roofs contribute to their toxicity and sedimentation (Van Metre \& Mahler, 2003). It has also been proven that metal roofs are a source of cadmium and zinc, and the asphalt used in roofing felt is a source of lead in the water flowing from the roofs (Beck, Johnson \& Spolek, 2011). In this light, green roofs are a solution that can have a positive impact on improving water quality.
In this study, the rainwater was sampled in April, May, June, July, August and September 2019. Measured values were recorded in the laboratory diary, and root growth inhibition/simulation was calculated. The calculation of mean root length also included non-germinated seeds with zero-root length. The resulting values indicated stimulation of root growth. If the result was $\leq 0$, the effect was stimulating, and if the result was $>0$, the effect was inhibiting (Kočí et al., 2001). Root growth stimulation (Fig. 4) for the individual share of rainwater sampled from April to September 2019 ranged from $-108 \%$ (in June) to $-142 \%$ (in May). The tests demonstrate that all the rainwater samples showed a stimulating effect on the test plant. The average root growth stimulation value during the period considered was $-125 \%$. It was confirmed that rainwater did not show toxic properties for white mustard seeds (Sinapis alba L.) and can be used to water roof garden of a selected research facility.

Figure 5 presents the $\mathrm{pH}$ value of rainwater. All rainwater samples were measured for $\mathrm{pH}$ immediately after collection from the tank. The $\mathrm{pH}$ value of rainwater sampled in April till September 2019 ranged respectively from 5.84 till 5.99 . The $\mathrm{pH}$ of the collected rainwater had a six-month average of $5.91 \pm 1.05$ (average \pm standard deviation).

The research shows that the $\mathrm{pH}$ of rainwater from the selected test facility did not have a toxic effect on the selected white mustard test plant (Sinapis alba L.). It proves that these waters can be used for watering the shopping centre's green roof. Wang, Tian and Zhao (2017) showed that the $\mathrm{pH}$ values in the outflow

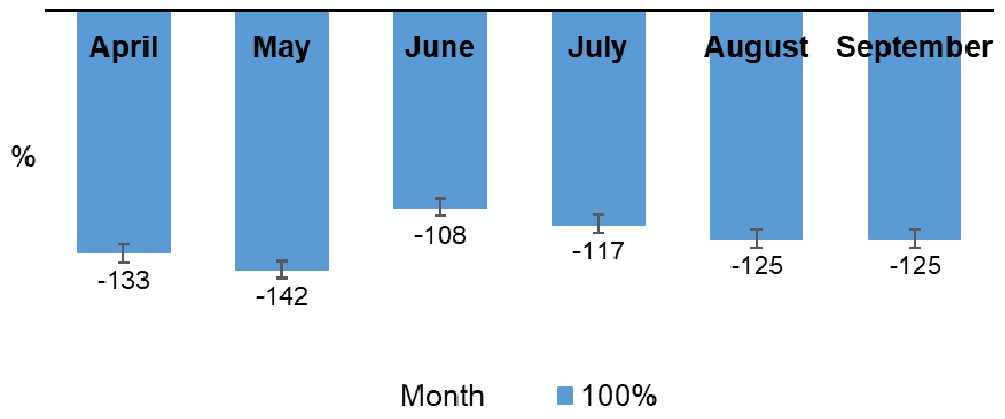

Fig. 4. Root length inhibition of rainwater from shopping centre "Sfera II" (average \pm standard deviation) 


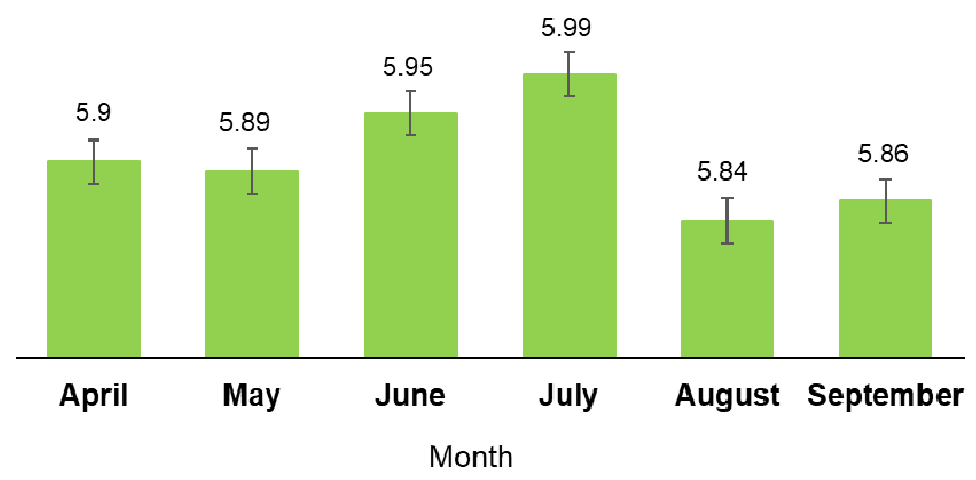

Fig. 5. The $\mathrm{pH}$ of rainwater from shopping centre "Sfera II" (average \pm standard deviation)

from the green roof they tested fluctuated between 6.5 and 7.6, which is higher than the $\mathrm{pH}$ of rainwater from the tested green roof. In a study by Gong, Wu, Peng, Zhao and Wang (2014), it was observed that double-layer green roof, as well as a single-layer one, alleviated mild acid rain. This is probably due to the high $\mathrm{pH}$ value of the substrate in green roof (Teemusk \& Mander, 2007). This neutralization of mild acid rain is an important environmental benefit that may contribute to a reduction in the acidity of water (Berndtsson, 2010) as well as soil in the surroundings of the site.

\section{Selected operational problems of green roofs}

Green roof is an old architectural concept, involving the garden construction on the top of a building to improve its biodiversity and insulation properties (Shafique, Kim \& Rafiq, 2018). Compared to standard roof it can survive for several dozen years without repairs. It is more durable than conventional one. However, it applies only to those, which are constructed correctly (Shafique et al., 2020). One of the main operational problems is the use of inadequate drainage (Tadeu, Simões, Almeida \& Manuel, 2019) or insulation. In Poland, the warranty for physical defects of a building is three years. The warranty is statutory, and therefore independent of the will of the parties. However, even in light of protection for physical defects, a green roof cannot be built just for the warranty period. If a green roof is faulty (e.g. due to inadequate drainage or insulation), it may be necessary to dismantle it, resulting in high construction costs almost from scratch. Consequently, design and the cooperation of specialists are very important at the design and implementation stage.

A very important element in green roof is to calculate the permissible ceiling loads appropriately. These loads are not the same in different sections of the roof. Builders' recommendations should be observed to avoid breakdown or construction disaster. Extensive roofs are easier to install and lighter, and thus can be installed on existing traditional roofs (Manso, Castro-Gomes, Paulo, Bentes \& Teixeira, 2018). Intensive green roofs are gardens with a rich variety of plants - from grasses, perennials, through shrubs and trees (Newton, Gedge, Early \& Wilson, 2007; Manso et al., 2018). These roofs effectively delay the outflow of rainwater. The vegetative layer, however, is very thick, from a meter to almost $2 \mathrm{~m}$. Due to its enormous weight, installing green roof on existing buildings is risky and challenging (Castleton, Stovin, Beck \& Davison, 2010; Vacek, Struhala \& Matějka, 2017). A very important construction aspect is the proper installation of waterproofing. Incorrect installation of waterproofing results in it to losing its anti-rupture properties. Waterproofing, which is not resistant to root outgrowth, cannot fulfill the proper function on a green roof. In this case, additional materials should be used (e.g. root protection foil), which increases the cost of construction (She \& Pang, 2010). In Poland, there are no standards that determine the resistance of a given material to root outgrowth. However, one can find a list of materials resistant to root growth on the German website of the 
Boas Berg, A., Adamcová, D., Martínez Barroso, P., Šourková, M., Vaverková, M. D. (2020). The impact of green roofs on the quality of rainwater and operational problems - case study. Acta Sci. Pol. Architectura, 19 (1), 31-41. doi: 10.22630/ASPA.2020.19.1.4

FLL institute. Therefore, to avoid operational problems (root outgrowth), it is worth using the highest quality waterproofing (www.dachyplaskie.info.pl).

Materials used to build layers of green roof have been studied by Bianchini and Hewage (2012). Its layers and materials are similar among manufacturers; however, each manufacturer has developed its proprietary system. General data on green roof systems is available. However, in most cases, a trade secret is maintained regarding substrate composition, production process, installation process and detailed technical data. Manufacturers usually keep this information confidential to gain a competitive advantage (Bianchini \& Hewage, 2012).

Proper care of plants, depending on whether it concerns Sedum mats in extensive roofs or trees and shrubs in intensive roofs, is one of the green roof exploitation problems. Appropriate plants and substrates for green roof should be used (Liu et al., 2019). Different substrates are used depending on the roof type. If an unsuitable substrate is used, it may inhibit plant growth. Where an organic substrate is used on an extensive roof, instead of growing sedum, unwanted weeds may appear (www.dachyplaskie. pl). The idea of ann extensive green roof is that it is supposed to have biologically unfavorable conditions and such that would allow succulents, plants that are very resistant to adverse weather conditions, to survive. A common mistake on extensive roofs is the use of plants with high habitat requirements. It prevents the plants from accumulating water in dry periods and consequently, causes them to die out. We encounter a more complicated situation in the case of intensive roofs (roof gardens), where it is important to secure trees and shrubs. They should have special underground reinforcements to prevent them from falling over during strong winds. Normal soil should not be used in ceiling substrates, as it usually contains float particles (e.g. clay), which are deposited on layers below (filtering non-woven fabric) and reduce its filtration properties and the formation of water stagnations. Too much peat should not be used. In intense green roof, the right choice of layers is an extremely important aspect. The selection of layers is important because of the functions of the roof space (fire exits communication routes, roof garden, etc.). The layers must be selected to ensure the entire roof system functions efficiently and safely for the building.

\section{CONCLUSIONS}

Green roofs are, for many reasons, a very good solution for highly developed urban areas. Their undoubted advantage is the increase of the biologically active area in urban areas. It is also an area that produces oxygen and reduces urban heat islands, as well as an attractive place, among others for honeybees and butterflies. When proper plant conditions are maintained, green roofs contribute to the preservation of endangered insect species. In addition to architects and engineers, specialists in landscape architecture or gardening should be involved in the design of green roofs. Succulents, i.e. plants with great water absorption capacity, are used on the extensive green roof. It is desirable to achieve roof properties that slow down runoff and increase evaporation. Intensive roofs have a thick vegetative layer, usually over a meter. Grasses, perennials, shrubs and small trees are planted on intensive roofs. Intensive roofs have very good retention properties due to the thicker soil layer and the presence of various plant species, including trees and shrubs. However, due to their enormous weight, they are often unsuitable for installation on existing buildings. The intensive roof in question required a special concrete structure that would support a large additional weight. The irrigation system is automatic, and following the green roof idea, rainwater collected under the object is used for irrigation. The research shows that rainwater used for watering the garden collected from the studied intensive roof is not toxic. The selected research facility meets the requirements for green roofs in terms of structural safety and operating conditions.

\section{REFERENCES}

Alsup, S., Ebbs, S. \& Retzlaff, W. (2010). The exchangeability and leachability of metals from select green roof growth substrates. Urban Ecosystems, 13 (1), 91-111.

Baryła, A., Gnatowski, T., Karczmarczyk, A. \& Szatyłowicz, J. (2019). Changes in Temperature and Moisture Content of an Extensive-Type Green Roof. Sustainability, 11 (9), 2498. doi: 10.3390/su11092498 
Boas Berg, A., Adamcová, D., Martínez Barroso, P., Šourková, M., Vaverková, M. D. (2020). The impact of green roofs on the quality of rainwater and operational problems - case study. Acta Sci. Pol. Architectura, 19 (1), 31-41. doi: 10.22630/ASPA.2020.19.1.4

Baryła, A., Karczmarczyk, A. \& Brandyk, A. (2018). The influence of a green roof drainage layer on retention capacity and leakage quality. Water Science and Technology, 77 (12), 2886-2895.

Baryła, A., Karczmarczyk, A. \& Bus, A. (2018). Role of Substrates Used for Green Roofs in Limiting Rainwater Runoff. Journal of Ecological Engineering, 19 (5), 86-92.

Beck, D. A., Johnson, G. R. \& Spolek G. A. (2011). Amending green roof soil with biochar to affect runoff water quantity and quality. Environmental Pollution, 159 (8-9), 2111-2118.

Berardi, U., Ghaffarian Hoseini, A. H \& Ghaffarian Hoseini, A. (2014). State-of-the-art analysis of the environmental benefits of green roofs. Applied Energy, 115, 411-428.

Berndtsson, J. C. (2010). Green roof performance towards management of runoff water quantity and quality: a review. Ecological Engineering, 36, 351-360.

Bianchini, F. \& Hewage, K. (2012). How "green" are the green roofs? Lifecycle analysis of green roof materials. Building and Environment, 48, 57-65.

Boas Berg, A., Jeznach, J., Radziemska, M., Adamcová, D. \& Brtnický, M. (2018). Rain water not in sewers but in the garden - the study case of the Netherlands and Polish experience. Acta Sci. Pol. Architectura, 17 (1), 79-88.

Bowler, D. E., Buyung-Ali, L., Knight, T. M. \& Pullin, A. S. (2010). Urban greening to cool towns and cities: a systematic review of the empirical evidence. Landscape and Urban Planning, 97 (3), 147-155.

Carpenter, D. D. \& Kaluvakolanu, P. (2011). Effect of roof surface type on storm-water runoff from full-scale roofs in a temperate climate. Journal of Irrigation and Drainage Engineering, 137 (3), 161-169.

Castleton, H. F., Stovin, V., Beck, S. B. M. \& Davison, J. B. (2010). Green roofs: building energy savings and the potential for retrofit. Energy and Buildings, 42, 1582-1591.

Francis, L. F. M. \& Jensen, M. B. (2017). Benefits of green roofs: A systematic review of the evidence for three ecosystem services. Urban Forestry and Urban Greening, $28,167-176$.

Getter, K. L. \& Rowe, D. B. (2009). Substrate depth influences Sedum plant community on a green roof. HortScience, 44 (2), 401-407.

Gong, K. N., Wu, Q., Peng, S., Zhao, X. H. \& Wang, X. C. (2014). Research on the characteristics of the water quality of rainwater runoff from green roofs. Water Science and Technology, 70 (7), 1205-1210.

Gregoire, B. G. \& Clausen, J. C. (2011). Effect of a modular extensive green roof on stormwater runoff and water quality. Ecological Engineering, 37 (6), 963-969.
Hathaway, A. M., Hunt, W. F. \& Jennings, G. D. (2008). A field study of green roof hydrologic and water quality performance. Transactions of the ASABE, 51 (1), $37-44$.

Hendel, I. (2007-2010). Projekt Galerii Sfera rozbudowa (wielofunkcyjny obiekt z galeria handlowa, hotelem, mieszkaniami) [Project Galeria Sfera expansion (multifunctional facility with a shopping gallery, hotel, apartments)]. Warszawa: Bielsko Business Center 2 Sp. z o.o.

Jungels, J., Rakow, D. A., Allred, S. B. \& Skelly, S. M. (2013). Attitudes and aesthetic reactions toward green roofs in the Northeastern United States. Landscape and Urban Planning, 117, 13-21.

Kočí, V., Rakovický T. \& Švagr, A. (2001). Test semichronické toxicity se semeny Sinapis alba [Semi-chronic toxicity test with Sinapis alba]. Praha: Vysoká škola chemicko-technologická v Praze. Retrieved from: http:// ekotoxikologie.sweb.cz/toxlab/vyuka/sinapis.htm\# Toc525630663

Law, E. P., Diemont, S. A. W \& Toland, T. R. (2017). A sustainability comparison of green infrastructure interventions using energy evaluation. Journal of Cleaner Production, 145, 374-385.

Lin, B. \& Zhu, J. (2018). Changes in urban air quality during urbanization in China. Journal of Cleaner Production, 188, 312-321.

Liu, J., Shrestha, P., Skabelund, L. R., Todd, T., Decker, A. \& Kirkham, M. B. (2019). Growth of prairie plants and sedums in different substrates on an experimental green roof in Mid-Continental USA. Science of The Total Environment, 697, 134089. doi: 10.1016/ j.scitotenv.2019.134089

Madre, F., Vergnes, A., Machon, N. \& Clergeau, P. (2014). Green roofs as habitats for wild plant species in urban landscapes: First insights from a large-scale sampling. Landscape and Urban Planning, 122, 100-107.

Manso, M., Castro-Gomes, J., Paulo, B., Bentes, I. \& Teixeira, C. A. (2018). Life cycle analysis of a new modular greening system. Science of The Total Environment, 627, 1146-1153.

Meera, V. \& Ahammed, M. (2006). Water quality of rooftop rainwater harvesting systems: a review. Water SRT - Aqua, 55, 257-268.

Newton, J., Gedge, D., Early, P. \& Wilson, S. (2007). Building Greener: Guidance on the Use of Green Roofs, Green Walls and Complementary Features on Buildings. London: CIRIA.

Ouldboukhitine, S. E., Belarbi, R. \& Sailor, D. J. (2014). Experimental and numerical investigation of urban street 
Boas Berg, A., Adamcová, D., Martínez Barroso, P., Šourková, M., Vaverková, M. D. (2020). The impact of green roofs on the quality of rainwater and operational problems - case study. Acta Sci. Pol. Architectura, 19 (1), 31-41. doi: 10.22630/ASPA.2020.19.1.4

canyons to evaluate the impact of green roof inside and outside buildings. Applied Energy, 114, 273-282.

Palermo, S. A., Turco, M., Principato, F. \& Piro, P. (2019). Hydrological effectiveness of an extensive green roof in Mediterranean climate. Water, 11 (7), 1378. doi: $10.3390 /$ w 11071378

Rozporządzenie Ministra Infrastruktury z dnia 14 stycznia 2002 r. w sprawie określenia przeciętnych norm zużycia wody. Dz.U. 2002 nr 8 poz. 70 [Regulation of the Minister of Infrastructure of 14 January 2002 on determining average standards of water consumption. Journal of Laws 2002 No 8, item 70].

Shafique, M., Azam, A., Rafiq, M., Ateeq, M. \& Luo, X. (2020). An overview of life cycle assessment of green roofs. Journal of Cleaner Production, 250, 119471. doi: 10.1016/j.jclepro.2019.119471

Shafique, M. \& Kim, R. (2017). Application of green blue roof to mitigate heat island phenomena and resilient to climate change in urban areas: a case study from Seoul, Korea. Journal of Water and Land Development, 33 (1), $165-170$.

Shafique, M., Kim, R. \& Rafiq, M. (2018). Green roof benefits, opportunities and challenges - a review. Renewable and Sustainable Energy Reviews, 90, 757-773.

She, N. \& Pang, J. (2010). Physically based green roof model. Journal of Hydrologic Engineering, 15 (6), 458-464.

Speak, A. F., Rothwell, J. J., Lindley, S. J. \& Smith, C. L. (2012). Urban particulate pollution reduction by four species of green roof vegetation in a UK city. Atmospheric Environment, 61, 283-293.

Stovin, V. (2010). The potential of green roofs to manage urban stormwater. Water Environment Journal, 24, 192 -199 .

Suter, I., Maksimović, Č. \& Reeuwijk, M. van (2017). A neighbourhood-scale estimate for the cooling potential of green roofs. Urban Climatology, 20, 33-45.

Tadeu, A., Simões, N., Almeida, R. \& Manuel, C. (2019). Drainage and water storage capacity of insulation cork board applied as a layer on green roofs. Construction and Building Material, 209, 52-65.
Teemusk, A. \& Mander, Ü. (2007). Rainwater runoff quantity and quality performance from a greenroof: the effects of short-term events. Ecological Engineering, 30 (3), 271-277.

Teotónio, I., Silva, C. M. \& Cruz, C. O. (2018). Eco-solutions for urban environments regeneration: the economic value of green roofs. Journal of Cleaner Production, 199, 121-135.

Todorov, D., Driscoll, C. T. \& Todorova, S. (2018). Longterm and seasonal hydrologic performance of an extensive green roof. Hydrological processes, 32, 2471-2482 .

Vacek, P., Struhala, K. \& Matějka, L. (2017). Life-cycle study on semi intensive green roofs. Journal of Cleaner Production, 154, 203-213.

Van Metre, P. \& Mahler B. (2003). The contribution of particles washed from rooftops to contaminant loading to urban streams. Chemosphere, 52 (10), 1727-1741.

Van Seters, T., Rocha, L., Smith, D. \& MacMillan, G. (2009). Evaluation of green roofs for runoff retention, runoff quality, and leachability. Water Quality Research Journal of Canada, 44 (1), 33-47.

Versini, P-A., Gires, A., Tchinguirinskaia, I. \& Schertzer, D. (2016). Toward an operational tool to simulate green roof hydrological impact at the basin scale: a new version of the distributed rainfall-runoff model Multi-Hydro. Water Science and Technology, 74, 1845-1854.

Versini, P-A., Gires, A., Tchiguirinskaia, I. \& Schertzer, D. (2020). Fractal analysis of green roof spatial implementation in European cities. Urban Forestry and Urban Greening, 49, 126629. doi: 10.1016/ j.ufug.2020.126629

Wang, X., Tian, Y. \& Zhao, X. (2017). The influence of dual-substrate-layer extensive green roofs on rainwater runoff quantity and quality. Science of The Total Environment, 592, 465-476.

Zhang, Q., Miao, L., Wang, X., Liu, D., Zhu, L., Zhou, B., Sun, J. \& Liu, J. (2015). The capacity of greening roof to reduce stormwater runoff and pollution. Landscape and Urban Planning, 144, 142-150. 


\section{WPŁYW ZIELONYCH DACHÓW NA JAKOŚĆ WODY DESZCZOWEJ ORAZ WYBRANE PROBLEMY EKOPLOATACYJNE - STUDIUM PRZYPADKU}

\section{STRESZCZENIE}

Centra handlowe zajmują zwykle duże powierzchnie zabudowy terenu, jednak ich dachy są rzadko wykorzystywane w celach związanych z zagospodarowaniem wód opadowych i wprowadzenia powierzchni biologiczne czynnych. W Bielsku-Białej, dzięki inicjatywie pomysłodawcy i architekta, powstał zielony dach intensywny na galerii handlowej. Dach ten przede wszystkim pełni funkcję ogrodu uatrakcyjniającego walory osiedla mieszkaniowego, ale również funkcję przejmowania części wód opadowych i opóźniania ich odpływu do kanalizacji. Rośliny, krzewy i drzewa posadzone na dachu są podlewane prawie wyłącznie wodą zgromadzoną w zbiorniku przeznaczonym do retencjonowania wód opadowych, znajdującym się pod budynkiem. Wody te są podczyszczone dzięki temu, że nim trafią do zbiornika, przesączają się przez warstwę korzeni roślin rosnących na dachu oraz przez warstwę biologicznie czynną (substrat). W niniejszej pracy zwrócono uwagę na niektóre problemy eksploatacyjne wybranego zielonego dachu. Skoncentrowano się również na ocenie toksyczności wód opadowych spływających z powierzchni utwardzonych na dachu galerii handlowej oraz z części zajmowanej przez zielony dach. Przeprowadzono w tym zakresie stosowne badania toksyczności tych wód. Postawiono hipotezę badawczą, że wody deszczowe przesiąkające przez wybrany materiał glebowy nie są toksyczne i stymulują wzrost rośliny testowej. Z przeprowadzonych subchronicznych testów toksyczności z zastosowaniem nasion gorczycy białej (Sinapis alba L.) wynika, że wszystkie próbki wód opadowych wykazywały stymulujący wpływ na roślinę testową. Średnia wartość stymulacji wzrostu korzeni w badanym okresie wynosiła $-125 \%$. Potwierdzono, że woda opadowa nie wykazywała toksycznych właściwości dla nasion gorczycy białej (Sinapis alba L.) i może być wykorzystywana do podlewania ogrodu stanowiącego zielony dach obiektu badawczego. W przypadku odczynu wód deszczowych stwierdzono, że pH jest odpowiednie i nie ma toksycznego wpływu na roślinę testową - gorczycę białą (Sinapis alba L.). Potwierdza to, że retencjonowane w ten sposób wody opadowe mogą być wykorzystywane do podlewania zielonego dachu. Wybrany obiekt badawczy spełnia wymagania stawiane zielonym dachom.

Słowa kluczowe: środowisko, zielony dach, woda deszczowa, test fitotoksyczności, Sinapis alba L. 